\title{
Mainstreaming ecosystem-based adaptation: transformation toward sustainability in urban governance and planning
}

\author{
Christine Wamsler $^{1,2,3}$
}

\begin{abstract}
The concept of ecosystem-based adaptation is advocated at international, national, and regional levels. The concept is thought to foster sustainability transitions and is receiving increasing interest from academic and governmental bodies alike. However, there is little theory regarding the pathways for its systematic implementation. It furthermore remains unclear to what degree the concept is already applied in urban planning practice, how it is integrated into existing planning structures and processes, and what drivers exist for further integration. Against this background, this study examines potential ways to sustainably mainstream ecosystembased adaptation into urban planning. Eight municipalities in Southern Germany were investigated to analyze the processes of mainstreaming ecosystem-based adaptation into current planning practice. Although the mainstreaming entry points for ecosystembased adaptation were identified to be appreciably different, the results of the study show how mainstreaming has generally led to patterns of change in: (1) on-the-ground measures, (2) organizational structures and assets, (3) formal and informal policies and instruments, (4) external cooperation and networking, and (5) the general working language. In all these areas, ecosystem-based adaptation to heat and flood risk is highly compartmentalized. Furthermore, although scholars have drawn attention to the risk of "mainstreaming overload," the results suggest that at the local level, the integration of ecosystem-based adaptation is strongly driven by departments' experience in mainstreaming other cross-cutting issues, namely environmental planning, climate change mitigation, and disaster risk management. Based on the findings, ways to leverage sustainability transitions via mainstreaming are discussed. It is concluded that systematic mainstreaming is a promising avenue for initiating and promoting local transitions and transformative adaptation. The study demonstrates the applicability of the presented mainstreaming framework for assessing and driving the mainstreaming capacity of local governments, thus also addressing the lack of related indicators highlighted in the Fifth Assessment Report of the United Nations Intergovernmental Panel on Climate Change (IPCC).
\end{abstract}

Key Words: adaptation; climate change; green infrastructure; landscape planning; municipal planning; resilience; risk reduction; sustainability transitions; sustainable transformation; urban planning; urban transformation

\section{INTRODUCTION}

Climate change poses a serious challenge to sustainable urban development and places cities at increasing risk (IPCC 2014). In the absence of adequate international responses and given the need for place-based adaptation, local authorities have a pivotal role in fostering sustainability transitions ${ }^{1}$ (Measham et al. 2011, Roberts et al. 2011, IPCC 2014, Rauken et al. 2014). However, climatic conditions are changing rapidly, as are their impacts on urban areas, including an increase in extreme precipitation, inland and coastal flooding, heat stress, drought, and water scarcity (IPCC 2014). As a result, the capacity of local authorities and associated governance systems to deal with climatic extremes and variability is being reduced (Romero Lankao 2008, Davoudi et al. 2010). New approaches for urban climate change adaptation are thus urgently needed.

The benefits of ecosystem-based approaches for climate change adaptation are proclaimed at the international level and their potential to foster sustainability transitions has received increased interest from scholars and governmental bodies alike (Andersson 2006, Roberts et al. 2011, Huq et al. 2013, Wilkinson et al. 2013, Chong 2014, IPCC 2014, Wu 2014). Ecosystem-based adaptation is a relatively new concept, which can be defined as the "use of biodiversity and ecosystem services as part of an overall adaptation strategy to help people to adapt" (CBD 2009:41). It aims to systematically harness the services of ecosystems to buffer communities against the adverse effects of climate change (Gill et al. 2007, Foster et al. 2011, Gaffin et al. 2012, Jones et al. 2012a, Munang et al. 2013). It thus advocates mainstreaming of both ecosystem services and climate change adaptation to foster sustainable planning and to comprehensively address the impacts of climatic extremes and variability (Kok and de Coninck 2007, Cowling et al. 2008, Vignola et al. 2009, Preston et al. 2010, Daily et al. 2011).

However, there is little theory about the pathways for systematic mainstreaming and institutionalization of ecosystem-based adaptation (Vignola et al. 2009, Andrade et al. 2011), and it thus remains unclear how local authorities can best integrate this new approach into their development plans and policies (IPCC 2014). Furthermore, little is known about the degree to which ecosystembased adaptation is already applied in urban planning practice (Turnpenny et al. 2014), how it is integrated into existing planning structures and processes, and what are the driving forces or barriers to further integration.

Against this background, this study examines potential ways to sustainably mainstream ecosystem-based adaptation into urban governance and planning. With in-depth studies of eight municipalities in Southern Germany, the study looks at how ecosystem-based adaptation is integrated into municipal planning practice, assesses the key characteristics of current mainstreaming

${ }^{1}$ Lund University Centre for Sustainability Studies (LUCSUS), Sweden, ${ }^{2}$ Centre for Societal Resilience (CSR), Sweden, ${ }^{3}$ Global Urban Research Centre (GURC), Manchester University, UK 
strategies, and analyzes their ability to foster sustainability transitions and transformative adaptation. The results are discussed and critically compared with other geographical contexts.

\section{ANALYTICAL FRAMEWORK}

Ecosystem-based adaptation is embedded in the theory and practice of ecosystem services and climate change adaptation planning (Uy and Shaw 2012a, $b$, Chong 2014). On the one hand, ecosystem services are "the conditions and processes through which natural ecosystems, and the species that make them up, sustain and fulfil human life" (Daily 1997:41). They include, but are not limited to, natural processes that regulate local climate, erosion, soil retention, water infiltration, and natural hazards (de Guenni et al. 2005, Smith et al. 2013, Larondelle et al. 2014). Developed to integrate ecological principles into economic considerations and local decision making (de Groot 1987, TEEB 2010), the ecosystem services concept is considered to be an effective way to advance sustainable urban planning (Ahern et al. 2014). Bearing this in mind, ecosystem service planning is a placebased approach that focuses on the creation, restoration, and conservation of ecological structures to provide society with specific services from nature (Chan et al. 2006, Staes et al. 2010). On the other hand, climate change adaptation focuses on the modification of human-environment features to moderate the adverse effects of climatic extremes and variability (Janssen et al. 2006, Thompson et al. 2006, IPCC 2007, Wamsler et al. 2013). Consequently, climate change adaptation planning assesses and modifies activities, policies, and the built environment according to the current and projected impacts of climate change and related societal vulnerabilities (Smit et al. 2000, Füssel 2007, Dannevig et al. 2012).

The need to mainstream the two conceptual components of ecosystem-based adaptation into urban planning, i.e., ecosystem services and climate change adaptation, is advocated in the scientific literature in these two fields (Daily and Matson 2008, Daily et al. 2009, Moser and Ekstrom 2010, Clar et al. 2013). Although the term "mainstreaming" often has no clear definition, it relates to a "perturbation in the natural order of things" (Picciotto 2002:323, La Trobe and Davis 2005) to integrate a new topic into existing and often ingrained ways of operating. Ultimately, mainstreaming is motivated by the need to change the dominant paradigm. It changes the rules of the game and challenges ideas, attitudes, or activities that are considered as mainstream or normal (Picciotto 2002). This relates, in turn, to the concepts of sustainability transitions (van den Bergh et al. 2011, Markard et al. 2012, Forrest and Wiek 2014), sustainable transformation (Westley et al. 2011, IPCC 2012, McCormick et al. 2013), and transformative adaptation. The latter is recognized for its potential to address root causes of risk and failures in sustainable development approaches (Revi et al. 2014).

A multipart mainstreaming framework is applied to systematically explore the potential ways in which ecosystembased adaptation can be integrated into urban planning. Mainstreaming approaches can be classified depending on whether they are based on horizontal or vertical integration, which characterizes the quality of governance relations between actors (Lafferty and Hovden 2003, Persson and Klein 2009, Rauken et al. 2014). The vertical dimension refers to implementation by powerful governmental bodies, such as city councils, and firm guidance from core legislative powers or actors during the integration process (Jacob and Volkery 2004). Horizontal integration can be defined as processes that are implemented by less powerful entities, such as departments, and specifically, conditions that are characterized by a single actor who encourages or coordinates mainstreaming, but who has insufficient authority to exercise top-down control (Jacob and Volkery 2004, Nunan et al. 2012).

Furthermore, the mainstreaming themes that emerge from the literature can be assigned to six strategic activities:

1. The initiation of new, on-the-ground activities that directly focus on the topic under consideration (Holden 2004, Roberts and O'Donoghue 2013, Wamsler 2014a);

2. The alignment of departments' activities on-the-ground to integrate the topic under consideration (Holden 2004, Pelling et al. 2008, Roberts and O'Donoghue 2013, Wamsler 2014a);

3. Strategic collaboration between relevant internal and external stakeholders (Holden 2004, Pelling et al. 2008, Roberts and O'Donoghue 2013, Sitas et al. 2014, Wamsler 2014a);

4. The modification of organizational working structures (Holden 2004, Pelling et al. 2008, Roberts and O'Donoghue 2013, Wamsler 2014a;

5. The revision and creation of policies, regulations, and instruments (Roberts and O'Donoghue 2013, Sitas et al. 2014, Wamsler 2014a); and

6. Directed instructions to support the integration of the topic under consideration (Pelling et al. 2008, Wamsler 2014a).

The mainstreaming framework developed by Wamsler (2014a) encompasses and consolidates these activities (Table 1).

\section{METHODS}

A multiple case-study approach (Yin 2009) was applied to analyze the key characteristics of activities regarding the integration of ecosystem-based adaptation into municipal planning. Eight municipalities in the Bavarian region of Southern Germany were analyzed, i.e., Munich, Nürnberg, Regensburg, Würzburg, Landshut, Passau, Deggendorf, and Freising (Fig. 1). Because of the exploratory character of the research, purposive sampling was used to select the municipalities (Flyvbjerg 2005, Tongco 2007) based on their hazard exposure regarding heat and flood and their proactive engagement in climate risk-related research groups or projects.

Germany is of particular interest. On the one hand, it expects substantial climate change impacts (DWD 2014). On the other hand, the country is portrayed as a pioneer in environmental and climate change governance (Foljanti Jost and Jacob 2004, DC 2014) and ecosystem-based approaches are promoted by the national government (BfN 2012). In addition, significant advances can be expected in the Bavarian region because of the commitment of the regional government to address climate change (StMUG 2009). 
Table 1. Mainstreaming framework.

\begin{tabular}{|c|c|}
\hline Dimensions $^{\dagger}$ & Mainstreaming Strategies \\
\hline \multicolumn{2}{|l|}{ Horizontal mainstreaming } \\
\hline (1) Add-on mainstreaming & $\begin{array}{l}\text { The establishment of specific on-the-ground projects or programs that are not an integral part of } \\
\text { the department's core work but directly target adaptation }{ }^{\dagger} \text { or related aspects. }\end{array}$ \\
\hline (2) Programmatic mainstreaming & $\begin{array}{l}\text { The modification of department's core work by integrating aspects related to adaptation }{ }^{\dagger} \text { into } \\
\text { on-the-ground operations, projects or programs. }\end{array}$ \\
\hline $\begin{array}{l}\text { (3) Inter- and intra-organizational } \\
\text { mainstreaming }\end{array}$ & $\begin{array}{l}\text { Promotes collaboration between individual sections or departments and other stakeholders, e.g., } \\
\text { other departments, committees, organizations, governmental bodies and civil society, to generate } \\
\text { shared knowledge, develop competence, and take joint actions to advance adaptation }{ }^{\dagger} \text {. }\end{array}$ \\
\hline \multicolumn{2}{|r|}{ о } \\
\hline (4) Managerial mainstreaming & $\begin{array}{l}\text { The modification of managerial and working structures, including internal formal and informal } \\
\text { norms and job descriptions as well as the configuration of sections or departments to better } \\
\text { address and institutionalize aspects related to adaptation }{ }^{\dagger} \text {. }\end{array}$ \\
\hline (5) Regulatory mainstreaming & $\begin{array}{l}\text { The modification of planning procedures and related activities, including formal and informal } \\
\text { plans, policies, regulations, and legislations that lead to the integration of adaptation }{ }^{\dagger} \text {. }\end{array}$ \\
\hline (6) Directed mainstreaming & $\begin{array}{l}\text { Supports or redirects the focus onto aspects related to integrating adaptation }{ }^{\dagger} \text { by e.g., providing } \\
\text { topic-specific funding, promoting new projects, supporting the education of staff, or directing } \\
\text { responsibilities. }\end{array}$ \\
\hline
\end{tabular}

${ }^{\dagger}$ The mainstreaming framework can be applied to overall adaptation, or specific aspects of it, e.g., ecosystem-based approaches, as well as to other cross-cutting topics such as climate change mitigation. Source: adapted from Wamsler et al. 2014 and Wamsler (2014a).

\section{Data collection}

In 2014, face-to-face interviews and a survey were conducted with staff from municipal departments engaged in spatial or environmental planning. Because proactive civil servants have been identified as key factors in adaptation mainstreaming (Roberts 2010), both the survey participants and the interviewees were selected through purposive sampling based on their field of activity within the municipality and their participation in adaptation and ecosystem-related activities. Fifteen in-depth interviews lasting at least two hours were carried out. The survey was designed to follow up on preliminary outcomes and triangulate data obtained from interviews and the literature. The literature review extended the analysis by providing contextual information on the selected cities, their activities, planning structures, and instruments, i.e., project documentations, organizational charts, job descriptions, municipal climate strategies, regional and sectoral plans, comprehensive and detailed plans, etc.

\section{Data analysis}

A combination of literal reading, grounded theory (Glaser and Strauss 1967, Corbin and Strauss 1990), and systems theory was applied. The identification and analysis of relevant passages from the data were organized into five phases: (1) coding scheme development in accordance with the analytical framework (previous section and Table 1), (2) identification of potentially relevant texts, (3) application of the coding scheme, (4) identification of change patterns, and (5) discussion of preliminary findings with key informants and staff from the municipalities and inclusion of their feedback. The latter also resulted in the development of an operational framework for adaptation mainstreaming (Wamsler 2014b), which is currently being tested in selected municipalities in Germany and Sweden. Related work allowed the review and validation of the leverage points for fostering sustainability transitions in local governments, which were identified in this study.

\section{RESULTS}

The results present the key characteristics and patterns of the identified activities that foster mainstreaming of ecosystem-based adaptation into municipal planning practice. A summary of the analysis for each city is given in Table 2. Based on the mainstreaming framework presented, the key patterns that were identified in the cross-case analysis relate to changes in on-theground measures (Table 1, strategies 1-2); organizational structures and assets, including internal cooperation (Table 1, strategies 3-4); formal and informal policies and instruments (Table 1, strategy 5); external cooperation and networking (Table 1 , strategy 3); and the use of the concept in professional jargon, which is often a prelude to action taking in the context of the previous issues. Directed mainstreaming (Table 1, strategy 6) was identified to be relevant for all listed aspects and is, thus, described under the respective subsections.

\section{Concepts in professional jargon}

The following change patterns were identified:

1. In contrast to climate change adaptation, climate change mitigation $^{2}$ has become an established term and focus area in sustainable municipal planning.

2. The concept of adaptation, if applied, is often used in a broad sense, as a buzzword, without further conceptualization.

3. The ecosystem services concept is generally not used and there is a clear reluctance toward doing so.

4. The ecosystem-based adaptation concept is not known.

5. Green infrastructure and the protection, maintenance, and creation of ecosystems are usually discussed in the context of heat, but not water-related risk.

Since the end of the 1990s, climate change mitigation has become an increasingly well-known term and is currently an explicit aim of sustainable municipal planning (Stadt Nürnberg 2009). In some instances, it is confused with adaptation or is used as an 
Fig. 1. Case study municipalities and respective levels of governance.

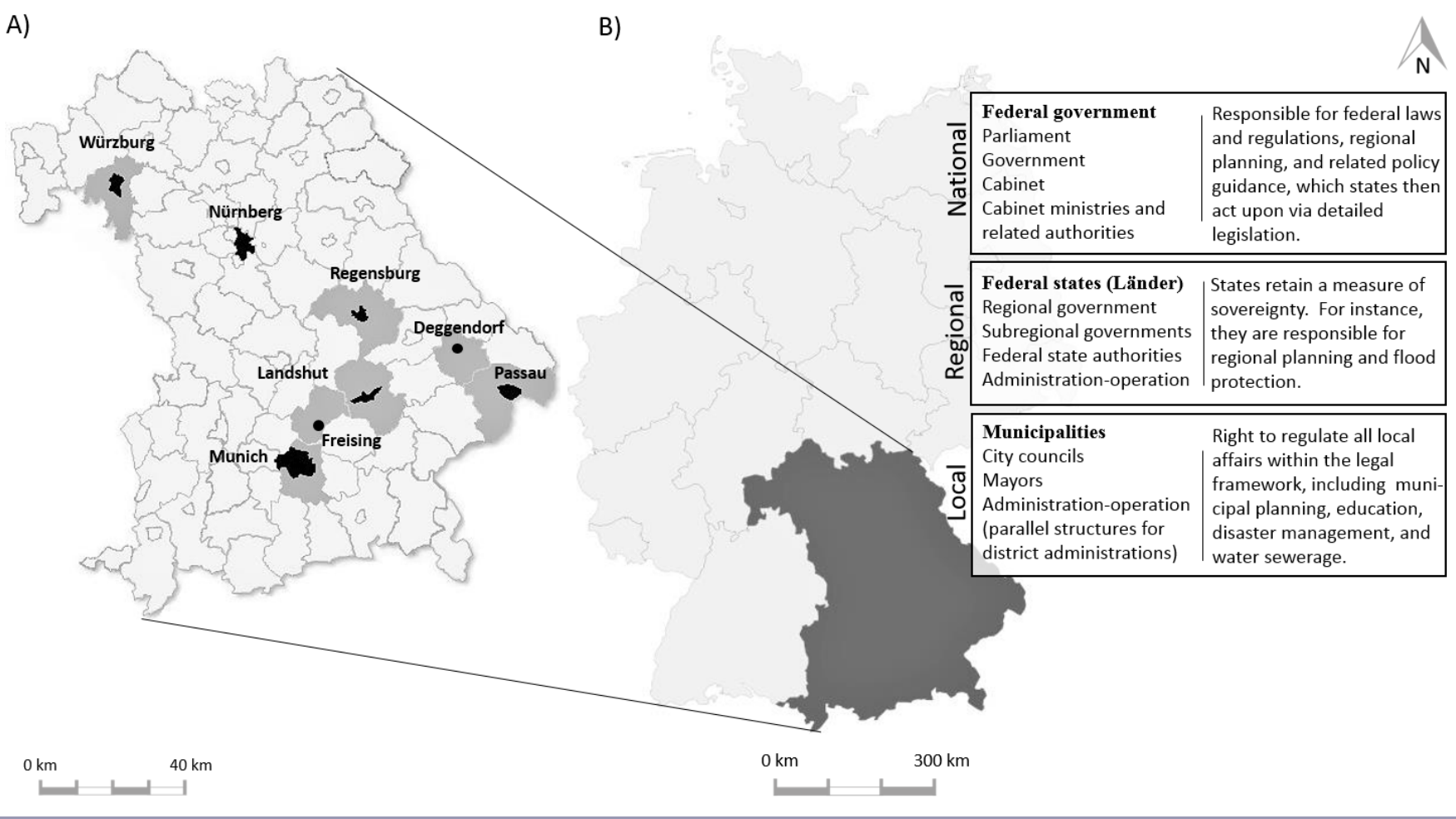

umbrella term for all types of measures that deal with both the causes and impacts of climate change. As one respondent explained: "The dominant term is climate change mitigation, currently everything is 'squeezed in' this term."

The term "climate change adaptation" is used less, and in two municipalities, Passau and Deggendorf, not at all. In Passau, climate change adaptation is, in accordance with its 2012 urban development strategy, only seen as "a topic for the future" (Stadt Passau 2012:21). In other cities, the adaptation concept started to become part of the professional jargon between 2009 and 2012. Proactive municipal staff started to find ways to put the concept onto the agenda, for instance in the context of climate protection strategies (e.g., in Munich) or the development of strategic development plans (e.g., in Freising). In some cities, e.g., Regensburg and Nürnberg, it was triggered by national funding, such as the open call for the research project Experimenteller Wohnungs- und Städtebau or ExWoSt, as it is commonly referred to (translation: experimental housing and urban planning). In Landshut, adaptation came up in late 2012, prompted by the position paper of the German Association of Cities (DST) on the issue (DST 2012). As was highlighted by some interviewees: "Climate change adaptation is certainly an issue for people interested in science, but to push the issue onto your own field of work ... it often needs an external trigger.”

In the past two years, in four municipalities, the concept has started to appear in strategic planning documents. However, even in these cases, its conceptualization is still in its infancy, which hinders systematic operationalization and mainstreaming. Similarly, the term "ecosystem-based adaptation" is not used yet by any municipality. After probing, alternative terminology such as "landscape-based adaptation" or "green and blue infrastructure" was suggested. Green and blue infrastructure is a commonly used concept, which highlights the importance of the natural environment, i.e., vegetation and water bodies, in decisions about land-use planning.

In all cases, except one, there is a general reluctance to use the ecosystem services concept. It is not thought to provide any added value to conventional approaches. Interviewees claim, however, that some key principles, e.g., existence and interconnectedness of different environmental functions and welfare effects, are essential components of their daily work, although they do not appreciate the importance of giving ecosystem services a monetary value. Most interviewees agree that: "Climate change mitigation and adaptation are services that cannot be valued in monetary terms. ... If we cannot get climate change under control, money will have no value any more. It is thus counterproductive to try to identify parameters with economic values."

Landshut was the exception. Here, the ecosystem services concept has been used since 2013 in strategic discussions with the city council, whose directorate comes from the private sector, and in expert evaluation of detailed or comprehensive planning. It was said to be easier to convey its meaning than the more commonlyused term "welfare effect."

In general, although the adaptation discourse is highly focused on temperature-related hazards, e.g., heat waves, tropical nights, etc., the terms "risk reduction" and "disaster risk management" dominate in the context of water-related hazards. Promoted by higher level authorities and changes in legislation, water-related 
Table 2. Key characteristics of single-case studies.

\begin{tabular}{|c|c|}
\hline $\begin{array}{l}\text { Cities } \\
\text { (population) }\end{array}$ & Key patterns of change and characteristics \\
\hline $\begin{array}{l}\text { Munich } \\
(\sim 1,500,000 \\
\text { inhabitants) }\end{array}$ & $\begin{array}{l}\text { - Environmental mainstreaming created an organizational structure that is advancing ecosystem-based adaptation (managerial and } \\
\text { interorganizational mainstreaming); } \\
\text { - High growth levels, together with the city's interest in pioneering new fields, are pushing ecosystem-based adaptation; } \\
\text { - Firm commitment to climate change mitigation also led to a number of explicit adaptation actions. Based on this, the development } \\
\text { of a separate adaptation strategy is underway (regulatory mainstreaming); } \\
\text { - Urban climate assessments created, as a by-product, a scientific knowledge base for future adaptation (Add-on and programmatic } \\
\text { mainstreaming); } \\
\text { - Organizational structures for adaptation mainstreaming, similar to those developed for climate change mitigation, have been } \\
\text { developed (managerial and interorganizational mainstreaming); } \\
\text { - On-the-ground actions are focused on low regret measures. Explicit adaptation measures are currently being planned (add-on and } \\
\text { programmatic mainstreaming). }\end{array}$ \\
\hline
\end{tabular}

Nürnberg -The city's participation in the nationwide adaptation research project ExWoSt advanced ecosystem-based adaptation (add-on ( 500,000 mainstreaming, etc.);

inhabitants) •ExWoSt resulted amongst other things in the development of a green and open space concept for the Weststadt area in 2012 with integrated adaptation, which has become a role model for the whole city and a basis for its adaptation strategy published in 2012 (regulatory mainstreaming);

- From 2012-2014 the focus has been on improving scientific knowledge (urban climate assessments) to create a better base for future adaptation (add-on mainstreaming);

- A climate roadmap was finalized in 2014, which includes adaptation. Because of a lack of assets and supporting structures, there are doubts regarding the sustainability of the achievements so far (lack of managerial mainstreaming).

Regensburg •Advances regarding adaptation are mainly based on the municipality's participation in the ExWoSt project in 2009-2013 (add-on $(\sim 140,000$ mainstreaming, etc.);

inhabitants) $\cdot$ In this context, a planning instrument was developed that is aimed at assisting the integration of adaptation into comprehensive planning (regulatory mainstreaming);

- The current revision of the comprehensive plan aims to include adaptation as an integrated component (regulatory mainstreaming); -A heritage management plan and a planning framework for the historic city center were developed with explicit consideration of adaptation-related issues, published in 2012 (regulatory mainstreaming);

- Participation in ExWoSt was the result of an initiative from municipal staff. There is little interest in adaptation from the city council (lack of directed mainstreaming);

- Adaptation is not integrated in the institutional structure/organization of the city and there are few related assets (lack of managerial mainstreaming);

- The lack of a climate protection program, an open space concept, and related internal working structures and procedures are hampering the institutionalization of adaptation (lack of regulatory mainstreaming);

- Progress in flood protection is closely related to regulation at higher levels, and led to the city's river basin strategy of 2010 (regulatory mainstreaming).

Würzburg -The preparation of the integrated climate protection plan published in 2012 led also to the promotion of adaptation measures (add$(\sim 130,000 \quad$ on and programmatic mainstreaming). In practice, their implementation is not actively pursued;

inhabitants) - Ongoing climate change mitigation and adaptation efforts focus on the establishment of a climate protection center for the general public, which aims to increase the knowledge of civil society and support individual actions (add-on mainstreaming). However, the focus to date has been on mitigation;

- Organizational structures were modified in 2010 to give climate protection an explicit value and foster its mainstreaming, which is pursued through existing processes, regulations, and tools (managerial mainstreaming). Adaptation is pursued along the same pathways;

- In practice, cold air production and fresh air corridors are the only adaptation measures that are actively pursued in development planning (programmatic mainstreaming).

Landshut - The organizational structure of the municipality was changed in 2005 , reflecting the reduced importance given to environmental ( 70,000 aspects in general (lack of managerial and intra-organizational mainstreaming);

inhabitants) - Adaptation is not part of the city council's areas of interest. Activities related to adaptation are based on the initiatives of municipal staff (lack of directed mainstreaming);

- Extreme population growth has led to personnel bottlenecks for detailed development planning and related time constraints for considering adaptation in this context (lack of regulatory mainstreaming);

- Flood and heat adaptation are unrelated;

- Firm commitment to biodiversity-related issues is, as a by-product, fostering ecosystem-based adaptation. 
Passau - Climate change adaptation is not yet a topic in municipal planning (lack of mainstreaming);

$(\sim 55,000 \quad$ - Flood risk management, one of the city's focus areas, is not connected to adaptation (lack of programmatic mainstreaming);

inhabitants) - Focus is on technical flood protection and, to a certain extent, more holistic flood risk management. These areas are under the direct control of higher level agencies and regulations (directed and regulatory mainstreaming);

-Increased involvement of citizens in flood protection is seen as a key to sustainably reduce risk; financial incentives were created to improve individual responsibility (programmatic and inter-organizational mainstreaming);

- The city has not yet developed a climate protection strategy (lack of regulatory mainstreaming).

Deggendorf - Activities related to climate change mitigation, adaptation, and environment need to be coordinated between the municipal

(City: $\sim 55,-$ administration and the administrative district office, a political structure that slows progress (difficult managerial and

$000 \quad$ interorganizational mainstreaming);

inhabitants; - The climate protection manager, employed in 2013, is unusually located within the planning department (managerial

District: mainstreaming);

$115,000 \quad$ Work on climate change mitigation is just starting; adaptation is not yet on the agenda. There is little political support for adaptation inhabitants) (lack of directed mainstreaming);

- Major flood protection work is not linked to adaptation (lack of programmatic mainstreaming);

- The city does not have an urban development strategy. This translates into a lack of an urban vision, which is hampering advances in adaptation (lack of regulatory mainstreaming);

- A lack of financial assets and personnel is seen as a key problem. External experts cannot be contracted (lack of managerial mainstreaming).

Freising - Climate change adaptation has been advanced through informal planning, namely the urban development plan (STEP), which (City: 50,- includes adaptation as an explicit field of activity (regulatory mainstreaming);

$000 \quad-$ Green and open space development is hampered because of lack of personnel and scattered responsibilities (like in Deggendorf), inhabitants; which also obstructs ecosystem-based adaptation (difficult managerial and interorganizational mainstreaming);

District: - Increasing political support for climate change mitigation has recently led to changes at various levels. Related influence on $170,000 \quad$ adaptation has not yet been identified (lack of managerial mainstreaming, etc.);

inhabitants) •Increased flood protection efforts were triggered by floods in 2013 as well as increasing demands from higher level authorities (directed mainstreaming). Related work was included in STEP as part of adaptation (regulatory mainstreaming). Focus is on ecosystem-based approaches (add-on and programmatic mainstreaming).

adaptation work has, since 2003 , been carried out under the heading of flood risk management, which has subsumed the older concept of technical flood protection (see also Policies and instruments).

\section{On-the-ground measures}

The following patterns of change regarding programmatic and add-on mainstreaming (Table 1) were identified:

1. Few explicit adaptation measures have been implemented on the ground.

2. The focus is on assessing local climate risk as an inevitable prerequisite for future adaptation measures.

3. Existing measures, which have adaptation as a cobenefit, or unintended by-product, were initiated by cities' increasing commitment to environmental planning, climate change mitigation, or flood risk management.

4. Most advances are related to riverine flood protection. Technical solutions dominate.

5. Heat-related measures are closely linked to ecosystembased approaches.

Because climate change adaptation is still a relatively new topic, there are few explicit adaptation measures, although there is a range of measures that have adaptation as a cobenefit. Many measures with adaptation cobenefits came out of environmental planning approaches and more recent climate change mitigation work. For instance, Agenda 21 projects now also include measures of ecosystem-based adaptation. In Munich, many of today's projects date from the 2001 urban development strategy,
Perspektive München (Stadt München 2001), its guideline on ecological planning (Stadt München 2012a), and the city's climate protection strategy (Stadt München 2012b). The resultant measures are the support of local recreation and mobility. They aim to reduce emissions by creating a pedestrian and bicycle-friendly environment, through the maintenance or development of green areas such as the Munich greenbelt, green corridors, open public spaces, and front yards. Another frequently used measure, which has adaptation cobenefits, is the promotion of green roofs.

Other measures with adaptation cobenefits have developed out of work on flood risk management. However, technical solutions dominate. Examples are the construction of water pumping stations, water detention basins, swales and storage sewers, the (re) construction of municipal buildings to improve resilience (e.g., in Passau) and, in all cities, improvements to existing embankments. In the words of an interviewee: "Regarding flood, it is all about building embankments. The protection of citizens is about building embankments. That this has anything to do with climate ... is not seen." Exceptional cases are the Isar renaturation project, which aimed to improve technical flood protection as well as provide ecological and recreational functions (WWA 2011) and Freising's integrated flood plan, which aims to reduce inflow to the Moosach river by improving water retention outside the city.

The first explicit adaptation measures came out of externally financed adaptation projects, cities' own climate mitigation work, or strategic development planning. In the case of Freising, the planning of ecosystem-based adaptation measures resulted from work on the urban strategic development plan (STEP). In Munich, the idea to create a climate adaptation theme park, currently in the 
planning phase, came out of its climate protection program (Stadt München 2012b). In Nürnberg and Würzburg, the identification of future measures is advanced and described in their respective integrative climate strategies (BAUM 2012, Stadt Nürnberg 2014). However, personnel, financial, and land-ownership issues have meant that implementation is slow. In Regensburg, only one measure, the uncovering of a historic stream and its development as recreational area in the Obermünster rehabilitation area, was approved and is underway. In several cases, active monitoring and selection of vegetation that is suitable for changing weather conditions has become part of daily practice in the municipalities' garden offices.

\section{Organizational structures and assets, including internal cooperation}

Regarding organizational structures and assets (Table 1, managerial and inter-organizational mainstreaming), the following patterns of change were identified:

1. Generally, there is no explicit and formally defined responsibility for climate adaptation.

2. In several places, climate protection managers also have minor, but nonformalized, responsibilities for adaptation.

3. There are few economic assets or personnel dedicated to adaptation. When there were external funds available, temporary organizational structures were often created to implement projects. After financing ended, these structures were dissolved and progress significantly slowed.

4. In the few cases in which adaptation has already led to changes in organizational structures, they are similar to those developed for climate change mitigation.

5. Since the 1980 s, many municipalities have gradually improved organizational structures to support environmental mainstreaming, which has also enhanced structures that support ecosystem-based adaptation.

Between 2013 and 2014 in many cities, the issue of climate change mitigation was formally included in their portfolio. Responsibility for climate change mitigation often lies with the highest decisionmaking levels. In all study areas, except Passau, one or several climate protection mangers were employed. They generally work in the environmental department and have the task of overall coordination and mainstreaming. There are two exceptions. The first is Deggendorf, where, in 2014, a climate protection manager was employed in the planning department. The second is Munich, where, in 2013-2014, a total of 11 climate protection managers were located in different units and departments to enable the topic to be integrated in a decentralized manner and at all planning levels.

In most cities climate protection managers were given, over time, minor, and only informal, responsibilities for addressing climate and weather-related impacts. In the case of Deggendorf, this extension of responsibilities was triggered by floods in 2013. In Landshut, it was related to the release of a position paper on climate change (DST 2012). In many other cities, it was a direct outcome of mitigation-related activities.

In seven of the eight municipalities, responsibility for adaptation is not explicitly defined and thus not part of its official activities.
The exception is Munich, where, in 2013, the city council decided to put adaptation on the agenda and employed a climate adaptation manager in the environmental department, a decision that developed out of the city's work on climate change mitigation, in particular its urban climate assessment. The role of the adaptation manager is to bring together and coordinate existing adaptation measures and, on this basis, develop an adaptation strategy. Between March and August 2014, an organizational structure was established to support the development of this strategy. This structure is composed of a steering and a working group, which both include various units and levels of decision makers. Interestingly, it is similar to the decentralized structure developed for the creation of the climate protection program (Stadt München 2010), and the working group includes several climate protection managers.

Other municipalities, in which adaptation mainstreaming has already led to changes in organizational structures and increased assets, have also replicated structures and processes similar to those developed for climate change mitigation, or even earlier, for environmental mainstreaming. The success of the latter varies considerably across areas. In Landshut, in 2005 the new mayor, from the private sector, decided to dismantle and subordinate the previously independent department for environmental protection to the office for public order to attract potential investors. In contrast, since the 1980s, Munich has developed an organizational structure aimed at integrating green infrastructure planning into all urban developments, a model that has received national attention. As a result, the local nature protection agency and the department for open space planning is today part of the urban planning unit, rather than the environmental unit. Although the department for open space planning is a separate department, its staff is physically located in various planning units. In practice, this means that for every city development, there is an urban planner who is directly supported by a landscape planner. This organizational structure and related working routines were established to mainstream environmental issues into planning at all levels and is now used to advance ecosystem-based adaptation.

However, in cases in which structures for mainstreaming other cross-sectoral topics are poorly developed, there is little progress in developing organizational structures and assets for adaptation mainstreaming. In these cases, developments are based on informal discussions and communication between staff members, and adaptation is often overlooked in favor of other pressing needs. In the words of one interviewee: "Based on the crazy population growth, which we currently have, nobody would have the time to establish or participate in any working groups [for climate change adaptation]. We have a real problem here."

Independent of the individual context, and in contrast to climate change mitigation, financial resources for climate change adaptation are generally lacking and have not yet led to a continuous integration process. In Regensburg and Nürnberg, adaptation was driven to a large extent by the ExWoSt project. When the project ended, "lost" personnel and financial capacity meant that the issue of adaptation could not be actively pursued. Other governmental funds for climate change adaptation, including adaptation strategies, were established in 2014 by the German Federal Ministry for the Environment, Nature Conservation and Nuclear Safety, interestingly as part of the 
ministry's funding program for climate change mitigation (BMUB 2014). Munich successfully applied for funding to establish their adaptation strategy.

Finally, scattered responsibilities for dealing with ecosystem services, climate-related risks, and disasters are seen as a challenge in all municipalities and especially smaller towns such as Freising and Deggendorf. In these towns, responsibility for green and open space development is fragmented because the district administration is responsible for environmental (and energy) issues and houses the local nature protection authority, whereas many other aspects are dealt with by the municipal administration, e.g., water- and traffic-related issues.

In the context of flood protection, responsibilities are well defined. The State of Bavaria has legal responsibility for major rivers, whereas city authorities are in charge of minor waterways. Within a municipality, the civil engineering department is generally responsible for flood protection and the municipal fire brigade, generally part of the civil protection department, is responsible for all types of disasters.

\section{Policies and instruments}

The identified patterns of change regarding formal and informal policies and instruments (Table 1, regulatory mainstreaming) are:

1. No city has, as yet, developed a separate climate adaptation strategy.

2. The integration of climate change adaptation, and of ecosystem-based adaptation in particular, into municipal policies and instruments is in its infancy.

3. Cities' commitment to climate change mitigation, environmental planning, and flood risk management has, as a by-product, also led to advances in the incorporation of ecosystem-based adaptation into policies and instruments.

4. Advances can mostly be found in informal strategic planning and instruments.

5. Instruments for fostering sustainable city planning do not include adaptation, including ecosystem-based adaptation, as an issue.

None of the cities in the study has, as yet, developed a standalone climate change adaption strategy. However, two cities, Nürnberg and Würzburg, have included adaptation as a component in their climate protection strategies. In Würzburg, an integrated mitigation-adaptation approach was promoted by a proactive staff member, leading to the endorsement of the city's integrated climate strategy in 2012 (BAUM 2012). In Nürnberg, the results of the ExWoSt project led to the development of a so-called adaptation handbook (Stadt Nürnberg 2012a), which presents the building blocks for an adaptation strategy based on the project's two pilot areas. Related aspects were then included in the 2014 climate roadmap, which presents climate change mitigation and adaptation as the two pillars of climate action (Stadt Nürnberg 2014). Munich has, at the end of 2013, initiated the process of elaborating a standalone adaptation strategy. In November 2013, the city council agreed to draw up such strategy and its commitment was reconfirmed in October 2014 when Munich became one of the first members of the European network "Mayors Adapt." As stated by one respondent: "We want to rise to the challenge ..... and show that we can do this."
None of the municipalities are making much effort to adjust existing formal or informal planning frameworks, regulations, and instruments to take into account the issue of climate change adaptation. Tables 3 and 4 provide an overview of existing and potential adaptation mainstreaming.

All interviewees agreed that comprehensive and detailed development plans and related policies, e.g., city statutes, were potentially the most important regulations for reducing weatherand climate-related risks. The revised building code of July 30 , 2011 states that climate change should be considered in any planning processes (BauGB 2011 §1). Accordingly, municipal staff can include (ecosystem-based) adaptation in existing formal planning instruments. However, in contrast to climate change mitigation, adaptation still receives little attention because of, among other things, a lack of guidance and local climate knowledge. From two of the interviewees: "Regarding the question of how to address climate-related issues in [the department of] comprehensive and detailed planning, how to integrate adaptation, I would argue that there is still a great need for research." "I could already include specific requirements [for adaptation], if I want to, but I lack the necessary basis for arguing why, in a certain place, I have to do it like this, and somewhere else perhaps not."

Current comprehensive plans were drawn up before adaptation became an important issue. In Regensburg, the comprehensive plan from 1983 is however now under revision to include climate change adaptation, an activity that was initiated by the ExWoSt project. This project also led to the development of a planning instrument for the integration of climatic aspects into comprehensive planning (Jacoby and Beutler 2013), which still needs to be tested.

In many areas, extreme growth has led to new detailed development plans with no time left for the issue of adaptation, except in terms of general standards. There are only a few developments in which additional measures were demanded to address problems such as water infiltration and increasing precipitation, e.g., a high percentage of green roofs in Munich and Freising.

Detailed development plans are seen as crucial for the promotion of hazard-resilient buildings and to prevent future construction in at-risk areas, although retroactive changes are unlikely. The resettlement or dismantling of existing constructions has not been planned, but related discussions have been initiated. The revision of existing detailed plans might mean that building permits in atrisk areas must be withdrawn, which would lead to the expropriation of private property that is constitutionally protected. This may lead to demands for compensation. Since 2013, the state has required that new developments can only be built in areas in which there is a 100-year flood protection guaranteed (WHG 2013).

Because formal planning is highly regulated and thus difficult and time consuming to modify, the integration of climate change adaptation, including ecosystem-based approaches, is mainly found in informal planning. An example is the guideline on ecological planning, which is part of Munich's urban development strategy, Perspektive München. It was updated in 2012 to integrate climate change-related issues (Stadt München 2012a). Accordingly, the planning department, which was mainly 
Table 3. Existing and potential adaptation mainstreaming in formal planning frameworks, policies, and instruments.

\begin{tabular}{|c|c|c|c|}
\hline \multicolumn{4}{|c|}{ Mainstreaming of ecosystem-based adaptation in formal planning ${ }^{\dagger}$} \\
\hline \multicolumn{2}{|c|}{ Planning frameworks and regulation } & \multicolumn{2}{|c|}{ Planning instruments } \\
\hline Existing adaptation mainstreaming & Potential adaptation mainstreaming & $\begin{array}{l}\text { Existing adaptation } \\
\text { mainstreaming }\end{array}$ & Potential adaptation mainstreaming \\
\hline $\begin{array}{l}\text { - Initial consideration of CCA as part } \\
\text { of the weighting principle specified in } \\
\text { the national construction code from } \\
2011 \text {; } \\
\text { - Climate-relevant requirements, e.g., } \\
\text { high percentage of green roofs, could } \\
\text { be regulated by some detailed plans } \\
\text { (Munich, Freising); } \\
\text { - Based on ExWoSt, revision of the } \\
\text { comprehensive plan from } 1983 \text { by } \\
\text { taking CCA into account. Planned } \\
\text { finalization in } 2016 \text { (Regensburg); } \\
\text { - Municipalities only plan and develop } \\
\text { urban areas in which protection is } \\
\text { guaranteed for a } 100 \text {-year flood; } \\
\text { - Restrictions on building usage and } \\
\text { construction in flood areas, e.g., since } \\
2014 \text { flood area regulation in Passau. }\end{array}$ & $\begin{array}{l}\text { - Explicit inclusion of CCA in } \\
\text { comprehensive and detailed plans; } \\
\text { - Inclusion of CCA in existing town } \\
\text { statutes, e.g., for tree preservation, } \\
\text { socially just land use, or the design of } \\
\text { front yards and open landscape, to } \\
\text { enhance CCA guidance. Since 2011, in } \\
\text { Landshut, CCA is informally included } \\
\text { in the statute for tree preservation; } \\
\text { - Establishment of a new town statute } \\
\text { for adaptation adequate land use; } \\
\text { - Adoption of a decision that allows } \\
\text { retroactive CCA improvements to be } \\
\text { demanded; } \\
\text { - Include CCA in criteria for the legal } \\
\text { definition of redevelopment areas. } \\
\text { Rehabilitation areas for CCM already } \\
\text { exist in Munich. }\end{array}$ & $\begin{array}{l}\text { - Inclusion of CCA } \\
\text { related arguments in } \\
\text { consultations and } \\
\text { professional opinions of } \\
\text { public bodies when } \\
\text { revising proposed } \\
\text { comprehensive and } \\
\text { detailed plans. }\end{array}$ & $\begin{array}{l}\text { - Based on urban climate assessments, if } \\
\text { they exist, a requirement to provide } \\
\text { climate reports for critical areas and } \\
\text { their inclusion in competitions for } \\
\text { detailed or comprehensive planning; } \\
\text { - Systematic and regulated inclusion of } \\
\text { CCA related aspects in environmental } \\
\text { impact assessments and environmental } \\
\text { reports; } \\
\text { - Systematic inclusion of CCA related } \\
\text { aspects in impact mitigation regulation } \\
\text { and related compensation; } \\
\text { - Establishment of urban-development } \\
\text { contracts between investors, i.e., house } \\
\text { builders, and municipal authorities, } \\
\text { which require CCA related measures; } \\
\text { - Improved CCA control mechanisms } \\
\text { included in detailed plans. }\end{array}$ \\
\hline
\end{tabular}

Related international, regional, or national guidance/instructions

- National construction code and its 2011 amendment on climate-related issues. Proposed: modification of article 34 regarding the construction of vacant lots in built-up areas to allow regulation of potential adaptation measures;

- The national protection law. Proposed: change to allow the issue of CCA to be a criterion for the declaration of landscape conservation areas;

- The Bavarian nature protection law;

- Bavarian building regulations;

- General planning guide published in 2013 by the Bavarian State Ministry of the Interior, Construction and Traffic (OBSI 2012/13). CCA is mentioned;

- Regional plan, and related plans for green and open space development, e.g., for the Munich region. It was revised two years ago to consider CCM and CCA issues under the heading of "environmental goods, climate, and air;"

- 2001 EU Directive on the assessment of the effects of plans and programs on the environment;

- 2007 EU directive on the assessment and management of flood risks;

- 2010 Federal government water resources act (WHG; article 78) requiring municipalities to plan and develop urban areas only where protection is guaranteed for a 100-year flood (HQ100). Municipalities must provide flood-risk maps by the end of 2013 and flood-risk management plans by the end of 2015 (WHG; articles 74 and 75). Inclusion of a 15\% addition for CC considerations;

- State water law of Bavaria prescribing that flood-risk maps have to include not only HQ100 but also HQExtrem (i.e., 1.5 times the water volume of HQ100);

- The Bavarian law for disaster and civil protection.

Selected examples mentioned by interviewees.

$\mathrm{CCA}=$ Climate change adaptation $; \mathrm{CCM}=$ Climate change mitigation $; \mathrm{CC}=$ Climate change .

responsible for the preparation of the guideline, started to mainstream adaptation into its strategic goals. In fact, its open space planning unit recently added a fifth pillar, called "climate change mitigation and adaptation" to its strategic goals.

In Nürnberg and Regensburg, the integration of climate change adaptation into informal planning was triggered by the ExWoSt project. In Nürnberg, it led to a green and open space concept for the Weststadt area of the city (Stadt Nürnberg 2012b). In Regensburg it led to the establishment of a heritage management plan (Stadt Regensburg 2012a) and a strategic planning framework for the historic city center (Stadt Regensburg 2014/15), all of which have adaptation considerations at their core.

In Freising, the issue of climate change adaptation was brought up during the development of the city's strategic urban development plan (STEP; Stadt Freising 2014/15). It is included under the heading "nature and landscape," indicating its close connection with ecosystem-based planning approaches. Although heat-related aspects were included from the beginning, flood protection was only included after floods in 2013 and in response to external demands, i.e., water legislation. Based on the STEP, in 2014 Freising began to develop an integrated flood protection and retention strategy.

Most changes in formal and informal planning have been initiated in the context of flood protection, which is related to regulation at European, national and regional levels. In 2010, the 2007 European Union (EU) directive on the assessment and management of floods was integrated into the federal government's water resources act. This outlined flood protection requirements and instructed municipalities to provide flood risk maps by the end of 2013 and flood risk management plans by the 
Table 4. Existing and potential adaptation mainstreaming in informal planning frameworks, policies, and instruments.

\begin{tabular}{|c|c|c|c|}
\hline \multicolumn{4}{|c|}{ Mainstreaming of ecosystem-based adaptation in informal planning ${ }^{\dagger}$} \\
\hline \multicolumn{2}{|c|}{ Planning frameworks and regulations } & \multicolumn{2}{|c|}{ Planning instruments } \\
\hline Existing adaptation mainstreaming & $\begin{array}{l}\text { Potential adaptation } \\
\text { mainstreaming }\end{array}$ & $\begin{array}{l}\text { Existing adaptation } \\
\text { mainstreaming }\end{array}$ & $\begin{array}{l}\text { Potential adaptation } \\
\text { mainstreaming }^{\dagger}\end{array}$ \\
\hline $\begin{array}{l}\text { - Integration of CCA into climate protection } \\
\text { strategies (Nürnberg, Würzburg); } \\
\text { - Decision to prepare an explicit adaptation strategy } \\
\text { (Munich); } \\
\text { - } 2012 \text { guideline on ecological planning, revised to } \\
\text { integrate CCM, and implicitly CCA aspects } \\
\text { (Munich); } \\
\text { - } 2014 \text { strategic urban development plan (STEP) with } \\
\text { integrated CCA (Freising); } \\
\text { - Climate adaptation handbook } 2012 \text { (Nürnberg); } \\
\text { - Green and open space concept for the Weststadt } \\
\text { district with integrated CCA from } 2012 \text { (Nürnberg); } \\
\text { - } 2012 \text { heritage management plan with integrated } \\
\text { CCA for the historic city center (Regensburg); } \\
\text { - Planning framework for the historic city center with } \\
\text { integrated CCA from 2014/15 (Regensburg); } \\
\text { - } 2010 \text { river basin strategy (Regensburg); } \\
\text { - Integral flood protection and retention plan } 2015 \\
\text { (Freising). }\end{array}$ & $\begin{array}{l}\text { - Development of a } \\
\text { separate strategic or } \\
\text { sectoral development plan } \\
\text { for CCA; } \\
\text { - Integration of CCA } \\
\text { related issues in strategic } \\
\text { or sectoral development } \\
\text { plans, e.g., for the } \\
\text { development of living } \\
\text { areas, river basins, } \\
\text { biodiversity, biotopes and } \\
\text { flora, fauna, and habitat } \\
\text { (FFH); } \\
\text { - Inclusion of CCA as an } \\
\text { aspect of sustainability } \\
\text { planning and reporting. }\end{array}$ & $\begin{array}{l}\text { - Better control of flood- } \\
\text { proof requirements } \\
\text { through city authorities } \\
\text { and chimney sweeps, e.g., } \\
\text { of secured oil tanks } \\
\text { (Deggendorf); } \\
\text { - In the context of floods, } \\
\text { inclusion of a } 15 \% \text { CCA } \\
\text { addition, e.g., STEP in } \\
\text { Freising; } \\
\text { - Development of an } \\
\text { informal guideline for the } \\
\text { integration of climatic } \\
\text { aspects into planning (i.e., } \\
\text { comprehensive planning } \\
\text { and related environmental } \\
\text { assessments) from } 2013 \\
\text { (Regensburg). }\end{array}$ & $\begin{array}{l}\text { - Establishment of design } \\
\text { guidelines for investors/builders, } \\
\text { which describe how the city would } \\
\text { like to see detailed development } \\
\text { plans and related CCA } \\
\text { requirements put into practice; } \\
\text { - Creation of advisory bodies to } \\
\text { provide assistance to investors/ } \\
\text { builders who must present and } \\
\text { discuss their ideas with these } \\
\text { bodies; } \\
\text { - Establishment of sustainability } \\
\text { criteria that include CCA. In } \\
\text { Munich general sustainability } \\
\text { aspects in detailed development } \\
\text { planning were developed in } 2012 .\end{array}$ \\
\hline \multicolumn{4}{|c|}{$\begin{array}{l}\text { Related international, regional, or national guidance/instructions } \\
\text { - General planning guide published in } 2013 \text { by the Bavarian State Ministry of the Interior, Construction and Traffic (OBSI 2012/13). CCA is } \\
\text { mentioned; } \\
\text { - } 1992 \text { EU directive on flora, fauna, and habitats (FFH); } \\
\text { - Guidelines from different associations, e.g., the German Association for Water, Sewage and Waste (DWA) and their recommendations for } \\
\text { handling rainwater runoff. Proposed: revision to include CCA related aspects; } \\
\text { - Various standards for water management from the German Institute for Standardization (DIN standards). }\end{array}$} \\
\hline
\end{tabular}

end of 2015 (WHG $2010 \S 74(6) 75(6)$ ). Adaptation is considered in the form of a $15 \%$ addition for calculating potential floods and related necessary flood protection.

Finally, although the issue of climate change mitigation is taken into account in sustainability planning and reporting, the interviewees stated that neither the issues of climate change adaptation nor ecosystem-based adaptation have been broached in this context (e.g., Stadt Nürnberg 2009, Stadt München 2012c)

\section{External cooperation and networking}

The identified patterns of change regarding intra-organizational mainstreaming (Table 1) are as follows:

1. Professional development takes place in the context of existing projects and, to some extent, networking events organized by national and international bodies.

2. Cooperation with neighboring municipalities and regional bodies exists mostly in the context of flood protection.

3. There is little cooperation with citizens and innovative alliances to support ecosystem-based adaptation.

The current focus of the selected cities is on their own administration and related capacity development, whereas little attention is given to external cooperation and networking. In the words of one interviewee: "The first step now is ... what is within our own competence ... what we can implement. And then we will look, in a second step, further, and try to include other processes [i.e., collaboration with external organizations and citizens]."

In contrast, external cooperation, city partnerships, networking, and collaborative arrangements have increasingly been fostered in the field of climate change mitigation in recent years (Gausset and Hoff 2013, Hoff and Gausset 2015).

Capacity building for adaptation is actively pursued by the five biggest cities through participation in projects or related dissemination events. These include the ExWoSt project (2009-2013) of the German Federal Ministry for the Environment, Nature Conservation and Nuclear Safety (BMUB); the Centre for Urban Ecology and Climate Adaptation ZSK 2013-16 financed by the Bavarian Ministry for Environment and Consumer Protection (StMUV); and the Klimmzug project (2008-2014) financed by the German Federal Ministry of Education and Research. In addition, staff from two cities, Munich and Würzburg, mentioned the importance of national and international networking events, such as climate dialogues held to discuss the national adaptation strategy, and workshops held by the European Commission's Climate Alliance, by the Covenant of Mayors, and by the Mayors Adapt networks. Not surprisingly, participation in these networks is often initiated by municipal staff, rather than the city council.

Because ecosystem-based adaptation is seen as extremely difficult because of space restrictions and the interests and concerns of 
the actors involved, there are very few cooperative arrangements or innovative alliances. In the words of one interviewee: [With all the different actors involved] "this is sometimes like trying to square the circle..., trying to achieve the impossible." The 2010 climate protection program developed by the city of Würzburg includes the creation of an urban climate network (BAUM 2012); no concrete actions have however been taken so far.

The importance of close cooperation with neighboring municipalities and governmental bodies responsible for regional planning was only mentioned in the context of water management and flood protection, with the regional water authority being the main actor. In Munich, the success of the Isar renaturation project was in fact considered to be the result of good cooperation and the constellation of actors involved.

In contrast to climate change mitigation, there is little citizen involvement and cooperation in climate change adaptation. In several cities it is restricted to the provision of basic information, mainly for flood protection. Four cities offer minor incentives aimed at reducing soil sealing and increasing greening on private lots. In the case of Nürnberg and Regensburg, these initiatives have been offered in the context of the ExWoSt project with limited success (Stadt Regensburg 2012b, Stadt Nürnberg, [date unknown]'). In Nürnberg, they are also based on environmental mainstreaming activities from the 1980s/90s. Also in Munich, related initiatives are relics of environmental mainstreaming work, i.e., the green courtyard project, which are now being revived or are linked to mitigation work. Regarding the latter, the nongovernmental organization Green City, supported by the Munich City Council as part of its climate protection program, established a greening office, which aims to engage citizens in adaptation.

Apart from the provision of information and minor financial incentives, there are few attempts to create further city-citizen collaborations. Freising asked residents to become "godparents" to two local stretches of water to ensure maintenance and flood control. In Freising and Munich, the city administrations have initiated a dialogue with residents and farmers in areas in which increased flood retention is difficult because of private land ownership.

\section{DISCUSSION}

The results provide rich and novel insights into current and potential activities that can foster the mainstreaming of ecosystem-based adaptation in urban governance and planning, related processes, advances, and shortcomings. All of the mainstreaming strategies investigated have been applied in practice, although the importance given to particular strategies and specific activities varies (see Results section and Table 2). The results highlight a gap between the concept of ecosystem-based adaptation and the practical implementation of related measures, synergies between the mainstreaming of ecosystem-based adaptation and other cross-cutting topics, ambiguities regarding the mainstreaming concept and, based on this, ways to leverage sustainability transitions. Although previous studies have noted similar aspects, in the context of this study, they played out in very different ways. Related comparative analyses are presented in the following subsections.

\section{Ecosystem-based adaptation in practice}

In theory, ecosystem-based adaptation is framed as a comprehensive approach rooted in both ecosystem services and climate change adaptation research (Uy and Shaw 2012a, b, Chong 2014); however, in practice, related activities are not linked to the ecosystem services concept. In contrast to other countries, where the ecosystem services concept has been identified as a key driver of ecosystem-based adaptation at national and local levels (Wamsler et al. 2014), in Germany it is perceived very critically.

Ecosystem-based approaches to adaptation are instead motivated by either environmental planning, or climate change adaptation, or flood risk management, and unlike other contexts (Doswald et al. 2014, Sitas et al 2014, Wamsler et al. 2014) are not labeled or systematized in any way. As described by one interviewee: "We deal with the issue of adaptation in a very broad or general sense, and the differentiation between constructive and other types of adaptation measures is, in practice, not yet a topic. We are not there yet. ... We still have a smörgasbord of ideas, we still don't have an overview. This will come with further conceptualization... Then we will perhaps start to systematize, and then perhaps also see where we have deficits, where we could advance adaptation in different ways."

Although mainstreaming entry points are diverse, progress in the mainstreaming of ecosystem-based adaptation tends to be associated with cities' commitment to environmental planning, rather than adaptation. This is because of increasing demands for sustainable growth, and the fact that environmental planning structures, processes, and instruments are, in contrast to other contexts, well established, which enables civil servants to engage in ecosystem-based adaptation within their current portfolio (Sitas et al. 2014, Wamsler et al. 2014). However, this applies mainly to heat risk.

Activities to reduce heat and flood risk were found to be compartmentalized. Related activities are mainly implemented independently. Although work on flood risk management is still dominated by technical solutions, activities related to heat risk are mostly based on green infrastructure approaches. However, the growing importance of the concept of flood risk management, as opposed to technical flood protection, supports increasingly integrated approaches, which advance ecosystem-based adaptation in practice.

\section{Mainstreaming synergies}

Synergies between top-down and bottom-up efforts

In line with a previous study on Swedish municipalities (Wamsler et al. 2014), this study shows the importance of combining mainstreaming strategies to balance the shortcomings in individual activities, including vertical and horizontal approaches.

Only in the case of flood protection is the mainstreaming of ecosystem-based adaptation characterized by clear guidance from core legislative powers and other actors at European, national, and regional levels. In the case of other climate-related risks, mainstreaming relates to the implementation of processes by departments that encourage or coordinate adaptation but have little authority themselves (cf. Jacob and Volkery 2004, Nunan et al. 2012). 
At the city level, although committed politicians are driving the integration of climate change mitigation, this is not the case for adaptation. Increasing regulation through directed mainstreaming has, for instance, been achieved in the context of climate change mitigation, e.g., through detailed-planning requirements or the definition of energy-rehabilitation projects, but it is still seen as politically difficult when it comes to adaptation.

A lack of directed mainstreaming is compensated for by dedicated civil servants who streamline the work within their sphere of activities. They submit applications for external, mainly national or regional, adaptation funding, push to join adaptation-related networks, and drive directed mainstreaming through integrating ecosystem-based adaptation into informal planning, thus laying the ground for the future integration into formal planning and decision making. However, in contrast to other countries (cf. Wamsler et al. 2014), there is little interest and engagement in accessing international funding or developing new planning instruments. The latter is because of high levels of regulation in Germany and the potential to adapt related processes and instruments, e.g., impact mitigation regulation and related compensation.

\section{Synergies between mainstreaming efforts}

This study revealed synergies between mainstreaming efforts, providing clear evidence that the mainstreaming of ecosystembased adaptation is enabled through experience in mainstreaming other topics (see under Organizational structures and assets and Policies and instruments). This finding is in contrast to older studies, such as Kok and de Coninck (2007) and Agrawala and Van Aalst (2008). Although more recent work has reported similar outcomes (Wamsler et al. 2014), it only relates to environment mainstreaming.

In the German context, both environmental and climate change mitigation planning have driven adaptation mainstreaming. Adaptation mainstreaming is most advanced in cities in which earlier efforts in environmental and, importantly, climate change mitigation mainstreaming have led to the creation of decentralized structures that promote interdisciplinary and interdepartmental work. Less progress is seen in those cities in which there is little environmental and climate change mitigation mainstreaming. Furthermore, strong synergies between climate change mitigation and adaptation planning were identified for both mainstreaming and on-the-ground operations, although past studies have mainly highlighted that "win-win solutions are rare" and "conflicting goals are ... commonplace" (McEvoy et al. 2006:190, Davoudi et al. 2010).

\section{Overcoming ambiguities regarding the mainstreaming concept}

Although the mainstreaming approach has received much criticism in the context of cross-cutting topics such as gender (Mazey 2002), environment (Dalal-Clayton and Bass 2009, Jordan and Lenschow 2010, Runhaar et al. 2014), disaster risk reduction (La Trobe and Davis 2005, Benson et al. 2007), HIV/ AIDS (Holden 2004), education and learning (Ferreira et al. 2007), and climate change mitigation and adaptation (Swart and Raes 2007, Adelle and Russel 2013), in the context of this study such concerns are hardly seen. The main criticisms of gender and environmental mainstreaming approaches are: (1) the risk of coopting the concept to promote issues that conflict with the targeted outcomes (Stratigaki 2005, True 2010, Weber and
Driessen 2010); (2) the risk of "mainstreaming overload" (Kok and de Coninck 2007:588, Agrawala and Van Aalst 2008:188); and (3) the risk that the new topic becomes nobody's responsibility (True 2010). Based on this, some scholars have concluded that mainstreaming is a technocratic exercise, which is unlikely to change social relationships (Palmary and Nunez 2009, Turnhout et al. 2013). Such ambiguities are not identified in this study. Because adaptation mainstreaming is built on past experience, processes, and structures of mainstreaming, related advances also build on the lessons learned and furthermore challenge conventional planning approaches, such as sectoral planning and technical flood protection. It is thus argued that criticism generally relates to a lack of comprehensive understanding and implementation of the mainstreaming concept in the past, which is different to the concept presented here, rather than problems inherent in the concept itself, which addresses potential counteracting forces.

In the past, mainstreaming processes have also led to the promotion of civil society involvement and collaborative arrangements with citizens to cocreate local policies and practice (Gausset and Hoff 2013, Hoff and Gausset 2015). The basic tenet is that citizens, either as individuals or as members of groups, can and must play an important part in related efforts (Tompkins and Eakin 2012, Gausset and Hoff 2013, Hoff and Gausset 2015). Surprisingly, there have been few such developments in the context of adaptation. This is confirmed by Naumann et al. (2011) who assessed ecosystem-based adaptation in Europe ${ }^{3}$. In the context of ecosystem-based adaptation, this is especially unfortunate because research on adaptive comanagement and adaptive governance has also shown the importance of civil society involvement and cross-level linkages for making the transition from uncoordinated or sector management, to ecosystem-based management (Olsson et al. 2004, Plummer and Armitage 2007, Plummer et al. 2012, 2013, Plummer 2013, Chaffin et al. 2014). Adaptive co-management and adaptive governance refers to governance of social-ecological systems for the management and use of assets that provide ecosystem services, in which rights and responsibilities are jointly shared between state-based and community-based systems.

Leveraging sustainability transitions through mainstreaming Like other studies, the ability of municipalities to implement mainstreaming was shown to depend on a range of contextual factors (cf. Burch 2010, van den Bergh et al. 2011, Dannevig et al. 2012), and is illustrated by this quote from an interviewee: "Advances are very different. They depend on individuals, their interests, the political standpoint of the mayor, the structure of the city council... Cities and districts work in a very complex way and are often very different. Overarching themes such as adaptation have, at an early stage, extreme amplitudes. There are cities that advance full speed, and there are cities that have startup difficulties. Once things are running, it develops a momentum of its own. Then a sort of social control kicks in between cities. 'They make it, then we also have to.' But at the initial stage, there are huge differences."

Apart from the commitment of individual staff members and prior mainstreaming experience, the size of the city and its associated resources were identified as particularly influential at all levels of mainstreaming, from capacity building to actual 
operations. Interviewees stated that: "Slowly, there is a rethink going on. I think that it is mainly in the bigger cities where a change in thinking can already be observed, and it is slowly coming to us too." "In the countryside, these issues [climate change mitigation and adaptation] still have a bad reputation... You are the bogeyman if you campaign for an issue that makes building areas more expensive, ... makes them difficult, or can impede the development of building areas"

Adaptation mainstreaming thus requires flexible strategies, which take into account context-specific features. Accordingly, there is no off-the-shelf template or step-by-step approach that could provide defined pathways for sustainably mainstreaming ecosystem-based adaptation into municipal governance and planning. Nevertheless, the framework presented addresses the claimed lack of indicators of local governments' mainstreaming capacity (IPCC 2014). The framework has been shown to be applicable to the analysis and comparison of both individual departments and entire city authorities. It is based on aspects identified as crucial, which are needed to develop momentum and make adaptation a core issue in municipal decision making. These include: the combination of different mainstreaming strategies and of related horizontal and vertical governance dimensions to overcome mainstreaming barriers; the encouragement of systematic planning for both explicit and implicit adaptation; and the involvement of a diversity of actors to enable innovative and sustainable solutions (cf. Ernstson et al. 2010), which include hard and soft (including ecosystem-based) measures (cf. Savacool 2011), as well as learning-by-doing approaches (cf. Kato and Ahern 2008, Jones et al. 2012b), while taking into account the local context.

\section{CONCLUSIONS}

This study investigated eight local government authorities in Southern Germany, i.e., Munich, Würzburg, Nürnburg, Regensburg, Landshut, Passau, Freising and Deggendorf, and looked at ways to mainstream ecosystem-based adaptation into municipal planning to foster sustainability transitions. First, the paper presents a systematic overview of current and potential mainstreaming activities and related processes. Second, it provides empirical evidence that there are diverse mainstreaming entry points for ecosystem-based adaptation and that environmental and climate change mitigation planning drive adaptation mainstreaming. Cities that have managed to integrate cross-cutting issues such as environment and climate change mitigation in the past are also more likely to have progressed in adaptation mainstreaming. Third, ecosystem-based adaptation is shown to be largely compartmentalized depending on how related activities are approached, i.e., via a climate change or disaster risk approach. Mainstreaming ecosystem-based adaptation would thus benefit from the creation of governance structures that combine well-established and highly directed flood risk management with climate change adaptation coordination, through defined decision-making bodies at different levels. Fourth, the paper highlights how mainstreaming strategies can complement and reinforce each other, and indicates ways to leverage sustainability transitions via mainstreaming in local government. The need for citizen-city collaborations to cocreate local policies and practice is underlined in this context. Fifth, the use of the developed mainstreaming framework to analyze current practice and capacities has been demonstrated, thus also providing initial indicators for local government's mainstreaming capacity. It has shown that adaptation mainstreaming in general, and the mainstreaming of ecosystem-based adaptation in particular, are still in their infancy. The applicability of the mainstreaming framework as a tool to make sustainability issues a core in local government decision making requires further research and is currently being tested in close collaboration with civil servants in pilot studies in Germany and Sweden. For this purpose, the results of this study have been translated into an operational guideline (Wamsler 2014b). Together with both the existing and the potential mainstreaming activities identified, it provides important input for municipalities to advance adaptation mainstreaming. Finally, further research might look into the applicability of the developed mainstreaming framework for identifying and characterizing transitions to adaptive comanagement and to describe related governance processes.

${ }^{[1]}$ Because of the specific characteristics (e.g., ambiguity and complexity) of sustainability problems, such as climate change, there is increasing consensus that incremental change is insufficient, and there is a need for more radical changes to achieve system-wide alterations that foster sustainability. These are here conceptualized as sustainability transitions.

${ }^{[2]}$ In contrast to climate change adaptation, which aims to reduce the effects of climate change, climate change mitigation aims to reduce the causes of climate change. Climate change mitigation commonly refers to anthropogenic interventions to reduce the sources, or enhance the sinks, of greenhouse gases (IPCC 2014). According to their respective aims, some measures can be classified as both climate change adaptation and climate change mitigation. Related overlaps can be intended or unintended.

${ }^{[3]}$ In contrast, in developing countries the mainstreaming of community-based approaches is increasingly advocated to achieve transformative adaptation (Archer et al. 2014).

Responses to this article can be read online at: http://www.ecologyandsociety.org/issues/responses. $\mathrm{php} / 7489$

\section{Acknowledgments:}

The research presented was carried out as part of a broader research project funded by the Swedish Research Council (FORMAS) and in cooperation with a project funded by the Bavarian State Ministry of the Environment and Consumer Protection (StMUV). I thank all partners for their contribution, namely the municipalities of Munich, Nürnberg, Regensburg, Würzburg, Landshut, Passau, Deggendorf, and Freising, as well as the Technical University of Munich (TUM), the Department of Strategic Landscape Planning and Management (SMLE), and the Centre for Urban Ecology and Climate Adaption (ZSK). Special thanks go to Professor S. Pauleit, Professor W. Lang, D. Gondhalekar, R. Hansen, E. Rall, W. Rolf, J. Tigges, W. Zehlius-Eckert, and H. Busch for their cooperation andlor valuable input.

\section{LITERATURE CITED}

Adelle, C., and D. Russel. 2013. Climate policy integration: a case of déjà vu? Environmental Policy and Governance 23:1-12. http:// dx.doi.org/10.1002/eet.1601 
Agrawala, S., and M. Van Aalst. 2008. Adapting development cooperation to adapt to climate change. Climate Policy 8:183-193. http://dx.doi.org/10.3763/cpol.2007.0435

Ahern, J., S. Cilliers, and J. Niemelä. 2014. The concept of ecosystem services in adaptive urban planning and design: a framework for supporting innovation. Landscape and Urban Planning 125:254-259. http://dx.doi.org/10.1016/j. landurbplan.2014.01.020

Andersson, E. 2006. Urban landscapes and sustainable cities. Ecology and Society 11(1): 34. [online] URL: http://www. ecologyandsociety.org/vol11/iss1/art34/

Andrade, A., R. Córdoba, R. Dave, P. Girot, B. Herrera-F, R. Munroe, J. Oglethorpe, P. Paaby, E. Pramova, J. Watson, and W. Vergara. 2011. Draft principles and guidelines for integrating ecosystem-based approaches to adaptation in project and policy design: a discussion document. IUCN, Gland, Switzerland. [online] URL: https://portals.iucn.org/library/efiles/edocs/2011-064. pdf

Archer, D., F. Almansi, M. DiGregorio, D. Roberts, D. Sharma, and D. Syam. 2014. Moving towards inclusive urban adaptation: approaches to integrating community-based adaptation to climate change at city and national scale. Climate and Development 6:345-356. http://dx.doi.org/10.1080/17565529.2014.918868

Baugesetzbuch (BauGb). 2011. Baugesetzbuch, Klimaschutznovelle, July 30, 2011 (§ 1; 171a-c).

Bayerisches Staatsministerium für Umwelt und Gesundheit (StMUG). 2009. Bayerische Klima-Anpassungsstrategie (BayKLAS). Bayerisches Staatsministerium für Umwelt und Gesundheit, Munich, Germany.

Benson, C., J. Twigg, and T. Rossetto. 2007. Tools for mainstreaming disaster risk reduction: guidance notes for development organizations. ProVention Consortium Secretariat, Geneva, Switzerland. http://www.preventionweb.net/english/ professional/publications/v.php?id=1066

B.A.U.M. Consult GmbH (BAUM). 2012. Integriertes Klimaschutzkonzept für die Stadt Würzburg. B.A.U.M Consult $\mathrm{GmbH}$ on behalf of Würzburg City, Würzburg, Germany.

Bundesamt für Naturschutz (BfN). 2012. Ökosystembasierte Ansätze zur Klimaanpassung und zum Klimaschutz im deutschsprachigen Raum. Project of the Federal Office for Nature Conservation (BfN), Bonn, Germany. [online] URL: http://www. ecologic.eu/de/7545

Bundesministerium für Umwelt, Naturschutz, Bau und Reaktorsicherheit (BMUB). 2014. Bekanntmachung des Bundesministerium für Umwelt, Naturschutz, Bau und Reaktorsicherheit (BMUB) über die Förderung von Maßnahmen zur Anpassung an den Klimawandel. BMUB, Berlin, Germany.

Burch, S. 2010. Transforming barriers into enablers of action on climate change: insights from three municipal case studies in British Columbia, Canada. Global Environmental Change 20:287-297. http://dx.doi.org/10.1016/j.gloenvcha.2009.11.009

Chan, K. M. A., M. R. Shaw, D. R. Cameron, E. C. Underwood, and G. C. Daily. 2006. Conservation planning for ecosystem services. PLoS Biology 4(11):e379. http://dx.doi.org/10.1371/ journal.pbio.0040379
Chaffin, B. C., H. Gosnell, and B. A. Cosens. 2014. A decade of adaptive governance scholarship: synthesis and future directions. Ecology and Society 19(3): 56. http://dx.doi.org/10.5751/ ES-06824-190356

Chong, J. 2014. Ecosystem-based approaches to climate change adaptation: progress and challenges. International Environmental Agreements: Politics, Law and Economics 14:391-405. http://dx. doi.org/10.1007/s10784-014-9242-9

Clar, C., A. Prutsch, and R. Steurer. 2013. Barriers and guidelines for public policies on climate change adaptation: a missed opportunity of scientific knowledge-brokerage. Natural Resources Forum 37:1-18. http://dx.doi.org/10.1111/1477-8947.12013

Corbin, J., and A. Strauss. 1990. Grounded theory research: procedures, canons, and evaluative criteria. Qualitative Sociology 13(1):3-21. http://dx.doi.org/10.1007/BF00988593

Cowling, R. M., B. Egoh, A. T. Knight, P. J. O’Farrell, B. Reyers, M. Rouget, D. J. Roux, A. Welz, and A. Wilhelm-Rechman. 2008. An operational model for mainstreaming ecosystem services for implementation. Proceedings of the National Academy of Sciences 105:9483-9488. http://dx.doi.org/10.1073/pnas.0706559105

Daily, G. C. 1997. Nature's services. Societal dependence on natural ecosystems. Island, Washington, D.C., USA.

Daily, G. C., P. M. Kareiva, S. Polasky, T. H. Ricketts, and H. Tallis. 2011. Mainstreaming natural capital into decisions. Pages 3-14 in P. Kareiva, H. Tallis, T. H. Ricketts, G. C. Daily, and S. Polasky, editors. Natural capital: theory and practice of mapping ecosystem services. Oxford University Press, Oxford, UK. http:// dx.doi.org/10.1093/acprof:oso/9780199588992.003.0001

Daily, G. C., and P. Matson. 2008. Ecosystem services: from theory to implementation. Proceedings of the National Academy of Sciences 105:9455-9456. http://dx.doi.org/10.1073/pnas.0804960105

Daily, G. C., S. Polasky, J. Goldstein, P. M. Kareiva, H. A. Mooney, L. Pejchar, T. H. Ricketts, J. Salzman, and R. Shallenberger. 2009. Ecosystem services in decision making: time to deliver. Frontiers in Ecology and the Environment 7:21-28. http:// dx.doi.org/10.1890/080025

Dalal-Clayton, B., and S. Bass. 2009. The challenges of environmental mainstreaming: experiences of integrating environment into development institutions and decisions. International Institute for Environment and Development, London, UK.

Dannevig, H., T. Rauken, and G. Hovelsrud. 2012. Implementing adaptation to climate change at the local level. Local Environment 17:597-611. http://dx.doi.org/10.1080/13549839.2012.678317

Davoudi, S., J. Crawford, and A. Mehmood, editors. 2010. Planning for climate change: strategies for mitigation and adaptation for spatial planners. Earthscan, London, UK.

de Groot, R. S. 1987. Environmental functions as a unifying concept for ecology and economics. Environmentalist 7:105-109. http://dx.doi.org/10.1007/BF02240292

de Guenni, L. B., M. Cardoso, J. Goldammer, G. Hurtt, L. J. Mata, K. Ebi, J. House, J. Valdes, and R. Norgaard. 2005. Regulation of natural hazards: floods and fires. Pages 441-454 in R. Hassan, R. Scholes, and N. Ash, editors. Ecosystems and human 
well-being: current state and trends. Oxford University Press, Oxford, UK. [online] URL: http://www.unep.org/maweb/en/ Condition.aspx

Doswald, N., R. Munroe, D. Roe, A. Giuliani, I. Castelli, J. Stephens, I. Möller, T. Spencer, B. Vira, and H. Reid. 2014. Effectiveness of ecosystem-based approaches for adaptation: review of the evidence-base. Climate and Development 6:185-201. http://dx.doi.org/10.1080/17565529.2013.867247

Deutscher Städtetag (DST). 2012. Positionspapier: Anpassung an den Klimawandel - Empfehlungen und Maßnahmen der Städte. Deutscher Städtetag, Köln, Germany.

Dual Citizen (DC). 2014. The global green economy index (GGEI) 2014: measuring national performance in the green economy. Fourth edition. Dual Citizen LLC, New York, New York, USA. [online] URL: http://dualcitizeninc.com/GGEI-Report2014.pdf

Deutscher Wetterdienst (DWD). 2014. Deutscher Klimaatlas. Deutscher Wetterdienst (DWD), Geschäftsbereich des Bundesministeriums für Verkehr und Digitale Infrastruktur (BMVI), Offenbach, Germany.

Ernstson, H., S. Barthel, E. Andersson, and S. T. Borgström. 2010. Scale-crossing brokers and network governance of urban ecosystem services: the case of Stockholm. Ecology and Society 15(4): 28. [online] URL: http://www.ecologyandsociety.org/ vol15/iss4/art28/

Ferreira, J.-A., L. Ryan, and D. Tilbury. 2007. Mainstreaming education for sustainable development in initial teacher education in Australia: a review of existing professional development models. Journal of Education for Teaching: International Research and Pedagogy 33:225-239. http://dx.doi.org/10.1080/02607470701259515

Flyvbjerg, B. 2005. Case study. Pages 301-316 in N. K. Denzin and Y. S. Lincoln, editors. Sage handbook of qualitative research. Sage, Thousand Oaks, California, USA.

Foljanti Jost, G., and K. Jacob. 2004. The climate change policy network in Germany. Environmental Policy and Governance. 14:1-15. http://dx.doi.org/10.1002/eet.337

Forrest, N., and A. Wiek. 2014. Learning from success - toward evidence-informed sustainability transitions in communities. Environmental Innovation and Societal Transitions 12:66-88. http://dx.doi.org/10.1016/j.eist.2014.01.003

Foster, J., A. Lowe, and S. Winkelman. 2011. The value of green infrastructure for urban climate adaptation. Center for Clean Air Policy, Washington, D.C., USA. [online] URL: http://ccap.org/ assets/The-Value-of-Green-Infrastructure-for-Urban-ClimateAdaptation CCAP-Feb-2011.pdf

Füssel, H.-M. 2007. Adaptation planning for climate change: concepts, assessment approaches, and key lessons. Sustainability Science 2:265-275. http://dx.doi.org/10.1007/s11625-007-0032-y

Gaffin, S. R., C. Rosenzweig, and A. Y. Y. Kong. 2012. Adapting to climate change through urban green infrastructure. Nature Climate Change 2:704. http://dx.doi.org/10.1038/nclimate1685

Gausset, Q., and J. Hoff, editors. 2013. Citizen driven environmental action. Special issue. Journal of Transdisciplinary Environmental Studies 12(1):1-3.
Gill, S. E., J. F. Handley, A. R. Ennos, and S. Pauleit. 2007. Adapting cities for climate change: the role of the green infrastructure. Built Environment 33:115-133. http://dx.doi. org/10.2148/benv.33.1.115

Glaser, B. G., and A. L. Strauss. 1967. The discovery of grounded theory: strategies for qualitative research. Aldine de Gruyter, New York, New York, USA.

Hoff, J., and Q. Gausset, editors. 2015. Community governance and citizen driven initiatives in climate change mitigation. Routledge/Earthscan, London, UK, and New York, New York, USA.

Holden, S. 2004. Mainstreaming HIVIAIDS in development and humanitarian programmes. Oxfam, Oxford, UK. [online] URL: http://www.toolkitsportdevelopment.org/html/resources/14/142B9325FD0A-4738-B13F-DD785E0BC0B8/mainstreaminghivaids.pdf http:// dx.doi.org/10.3362/9780855987909

Huq, N., F. Renaud, and Z. Sebesvari. 2013. Ecosystem based adaptation (EBA) to climate change integrating actions to sustainable adaptation. United Nations University, Institute for Environment and Human Security, Bonn, Germany. [online] URL: http://www.climate-impacts-2013.org/files/cwi huq.pdf

Intergovernmental Panel on Climate Change (IPCC). 2007. Climate change 2007: impacts, adaptation and vulnerability. Contribution of working group II to the fourth assessment report of the Intergovernmental Panel on Climate Change. Cambridge University Press, Cambridge, UK. https://www.ipcc.ch/ publications and datapublications ipcc fourth_assessment_report wg2 report impacts adaptation and vulnerability.htm

Intergovernmental Panel on Climate Change (IPCC). 2012. Managing the risks of extreme events and disasters to advance climate change adaptation. A special report of working groups I and II of the Intergovernmental Panel on Climate Change. Cambridge University Press, Cambridge, UK. http://ipcc-wg2. gov/SREX/report/

Intergovernmental Panel on Climate Change (IPCC). 2014. Climate change 2014: impacts, adaptation, and vulnerability. Cambridge University Press, Cambridge, UK. http://www.ipcc. ch/report/ar5/wg2/

Jacob, K., and A. Volkery. 2004. Institutions and instruments for government self-regulation: environmental policy integration in a cross-country perspective. Journal of Comparative Policy Analysis: Research and Practice 6:291-309. http://dx.doi. org/10.1080/1387698042000305211

Jacoby, C., and K. Beutler. 2013. Integration einer Klimafolgenabschätzung in die Umweltpüfung zum Flächennutzungsplan. ExWoSt, Regensburg, Germany.

Janssen, M. A., M. L. Schoon, W. Ke, and K. Börner. 2006. Scholarly networks on resilience, vulnerability and adaptation within the human dimensions of global environmental change. Global Environmental Change 16:240-252. http://dx.doi. org/10.1016/j.gloenvcha.2006.04.001

Jones, H. P., D. G. Hole, and E. S. Zavaleta. 2012a. Harnessing nature to help people adapt to climate change. Nature Climate Change 2:504-509. http://dx.doi.org/10.1038/nclimate1463 
Jones, K. B., G. Zurlini, F. Kienast, I. Petrosillo, T. Edwards, T. G. Wade, B.-L. Li, and N. Zaccarelli. 2012b. Informing landscape planning and design for sustaining ecosystem services from existing spatial patterns and knowledge. Landscape Ecology 28:1175-1192. http://dx.doi.org/10.1007/s10980-012-9794-4

Jordan, A., and A. Lenschow. 2010. Environmental policy integration: a state of the art review. Environmental Policy and Governance 20:147-158. http://dx.doi.org/10.1002/eet.539

Kato, S., and J. Ahern. 2008. "Learning by doing:" adaptive planning as a strategy to address uncertainty in planning. Journal of Environmental Planning and Management 51:543-559. http:// dx.doi.org/10.1080/09640560802117028

Kok, M. T. J., and H. C. de Coninck. 2007. Widening the scope of policies to address climate change: directions for mainstreaming. Environmental Science and Policy 10:587-599. http://dx.doi.org/10.1016/j.envsci.2007.07.003

La Trobe, S., and I. Davis. 2005. Mainstreaming disaster risk reduction: a tool for development organisations. Tearfund, Middlesex, UK.

Lafferty, W., and E. Hovden. 2003. Environmental policy integration: towards an analytical framework. Environmental Politics 12:1-22. http://dx.doi.org/10.1080/09644010412331308254

Larondelle, N., D. Haase, and N. Kabisch. 2014. Mapping the diversity of regulating ecosystem services in European cities. Global Environmental Change 26:119-129. http://dx.doi. org/10.1016/j.gloenvcha.2014.04.008

Markard, J., R. Raven, and B. Truffer. 2012. Sustainability transitions: an emerging field of research and its prospects. Research Policy 41:955-967. http://dx.doi.org/10.1016/j.respol.2012.02.013

Mazey, S. 2002. Gender mainstreaming strategies in the E.U.: delivering on an agenda? Feminist Legal Studies 10:227-240. http://dx.doi.org/10.1023/A:1021223828355

McCormick, K., S. Anderberg, L. Coenen, and L. Neij. 2013. Advancing sustainable urban transformation. Journal of Cleaner Production 50:1-11. http://dx.doi.org/10.1016/j.jclepro.2013.01.003

McEvoy, D., S. Lindley, and J. Handley. 2006. Adaptation and mitigation in urban areas: synergies and conflicts. Municipal Engineer 159:185-191. http://dx.doi.org/10.1680/muen.2006.159.4.185

Measham, T. G., B. L. Preston, T. F. Smith, C. Brooke, R. Gorddard, G. Withycombe, and C. Morrison. 2011. Adapting to climate change through local municipal planning: barriers and challenges. Mitigation and Adaptation Strategies for Global Change 16:889-909. http://dx.doi.org/10.1007/s11027-011-9301-2

Moser, S. C., and J. A. Ekstrom. 2010. A framework to diagnose barriers to climate change adaptation. Proceedings of the National Academy of Sciences 107:22026-22031. http://dx.doi.org/10.1073/ pnas. 1007887107

Munang, R., I. Thiaw, K. Alverson, M. Mumba, J. Liu, and M. Rivington. 2013. Climate change and ecosystem-based adaptation: a new pragmatic approach to buffering climate change impacts. Current Opinion in Environmental Sustainability 5:67-71. http://dx.doi.org/10.1016/j.cosust.2012.12.001
Naumann, S., G. Anzaldua, P. Berry, S. Burch, M. Davis, A. Frelih-Larsen, H. Gerdes, and M. Sanders. 2011. Assessment of the potential of ecosystem-based approaches to climate change adaptation and mitigation in Europe. Final report to the European Commission, DG Environment. Ecologic institute and Environmental Change Institute, Oxford University Centre for the Environment, Oxford, UK. [online] URL: http://ec.europa. eu/environment/nature/climatechange/pdf/EbA_EBM_CC_FinalReport. pdf

Nunan, F., A. Campbell, and E. Foster. 2012. Environmental mainstreaming: the organizational challenges of policy integration. Public Administration and Development 32:262-277. http://dx.doi.org/10.1002/pad.1624

Oberste Baubehörde im Bayerischen Staatsministerium des Innern (OBSI). 2012/3. Planungshilfen für die Bauleitplanung: Hinweise für die Ausarbeitung und Aufstellung von Flächennutzungsplänen und Bebauungsplänen. Oberste Baubehörde im Bayerischen Staatsministerium des Innern (OBSI), Munich, Germany.

Olsson, P., C. Folke, and T. Hahn. 2004. Social-ecological transformation for ecosystem management: the development of adaptive comanagement of a wetland landscape in southern Sweden. Ecology and Society 9(4): 2. [online] URL: http://www. ecologyandsociety.org/vo19/iss4/art2/

Palmary, I., and L. Nunez. 2009. The orthodoxy of gender mainstreaming: reflecting on gender mainstreaming as a strategy for accomplishing the millennium development goals. Journal of Health Management 11:65-78. http://dx.doi.org/10.1177/097206$\underline{340901100105}$

Pelling, M., C. High, J. Dearing, and D. Smith. 2008. Shadow spaces for social learning: a relational understanding of adaptive capacity to climate change within organisations. Environment and Planning A 40:867-884. http://dx.doi.org/10.1068/a39148

Persson, Å., and R. J. T. Klein. 2009. Mainstreaming adaptation to climate change into official development assistance: challenges to foreign policy integration. Pages 162-177 in P. G. Harris, editor. Climate change and foreign policy: case studies from East to West. Routledge, London, UK.

Picciotto, R., 2002. The logic of mainstreaming: a development evaluation perspective. Evaluation 8:322-339. http://dx.doi. org/10.1177/135638902401462420

Plummer, R. 2013. Can adaptive comanagement help to address the challenges of climate change adaptation? Ecology and Society 18(4): 2. http://dx.doi.org/10.5751/ES-05699-180402

Plummer, R., and D. R. Armitage. 2007. Charting the new territory of adaptive co-management: a Delphi study. Ecology and Society 12(2): 10. [online] URL: http://www.ecologyandsociety. org/vol12/iss $2 / \operatorname{art} 10 /$

Plummer, R., D. R. Armitage, and R. C. de Loë. 2013. Adaptive comanagement and its relationship to environmental governance. Ecology and Society 18(1): 21. http://dx.doi.org/10.5751/ ES-05383-180121

Plummer, R., B. Crona, D. R. Armitage, P. Olsson, M. Tengö, and O. Yudina. 2012. Adaptive comanagement: a systematic 
review and analysis. Ecology and Society 17(3): 11. http://dx.doi. org/10.5751/ES-04952-170311

Preston, B. L., R. M. Westaway, and E. J. Yuen. 2010. Climate adaptation planning in practice: an evaluation of adaptation plans from three developed nations. Mitigation and Adaptation Strategies for Global Change 16(4):407-438. http://dx.doi. org/10.1007/s11027-010-9270-X

Rauken, T., P. K. Mydske, and M. Winsvold. 2014. Mainstreaming climate change adaptation at the local level. Local Environment 20:408-423. http://dx.doi.org/10.1080/13549839.2014.880412

Revi, A., D. Satterthwaite, F. Aragón-Durand, J. Corfee-Morlot, R. B. R. Kiunsi, M. Pelling, D. Roberts, W. Solecki, S. P. Gajjar, and A. Sverdlik. 2014. Towards transformative adaptation in cities: the IPCC's fifth assessment. Environment and Urbanization. 26:11-28. http://dx.doi.org/10.1177/0956247814523539

Roberts, D. 2010. Prioritizing climate change adaptation and local level resilience in Durban, South Africa. Environment and Urbanization. 22:397-413. http://dx.doi.org/10.1177/0956247810379948

Roberts, D., R. Boon, N. Diederichs, E. Douwes, N. Govender, A. Mcinnes, C. Mclean, S. O'Donoghue, and M. Spires. 2011. Exploring ecosystem-based adaptation in Durban, South Africa: "learning-by-doing" at the local government coal face. Environment and Urbanization 24:167-195. http://dx.doi. org/10.1177/0956247811431412

Roberts, D., and S. O’Donoghue. 2013. Urban environmental challenges and climate change action in Durban, South Africa. Environment and Urbanization 25:299-319. http://dx.doi. org/10.1177/0956247813500904

Romero Lankao, P., 2008. Urban areas and climate change: review of current issues and trends. Issues Paper for the 2011 Global Report on Human Settlement. UN-Habitat, Nairobi, Kenya.

Runhaar, H., P. Driessen, and C. Uittenbroek. 2014. Towards a systematic framework for the analysis of environmental policy integration. Environmental Policy and Governance 24:233-246. http://dx.doi.org/10.1002/eet.1647

Secretariat of the Convention on Biological Diversity (CBD). 2009. Connecting biodiversity and climate change mitigation and adaptation: report of the second ad hoc technical expert group on biodiversity and climate change. Technical series No. 41. Secretariat of the Convention on Biological Diversity, Montreal, Quebec, Canada. [online] URL: http://www.cbd.int/doc/ publications/cbd-ts-41-en.pdf

Sitas, N., H. E. Prozesky, K. J. Esler, and B. Reyers. 2014. Exploring the gap between ecosystem service research and management in development planning. Sustainability 6:3802-3824. http://dx.doi.org/10.3390/su6063802

Smit, B., I. Burton, R. J. T. Klein, and J. Wandel. 2000. An anatomy of adaptation to climate change and variability. Climate Change 45:223-251. http://dx.doi.org/10.1023/A:1005661622966

Smith, P., M. R. Ashmore, H. I. J. Black, P. J. Burgess, C. D. Evans, T. A. Quine, A. M. Thomson, K. Hicks, and H. G. Orr. 2013. REWIEW: The role of ecosystems and their management in regulating climate, and soil, water and air quality. Journal of Applied Ecology 50:812-829. http://dx.doi.org/10.1111/1365-2664.12016
Sovacool, B. K. 2011. Hard and soft paths for climate change adaptation. Climate Policy 11:1177-1183. http://dx.doi. org/10.1080/14693062.2011.579315

Staes, J., D. Vrebos, and P. Meire. 2010. A framework for ecosystem services planning. Pages 53-72 in P. H. Liotta, W. G. Kepner, J. M. Lancaster, and D. A. Mouat, editors. Achieving environmental security: ecosystem services and human welfare. IOS, Amsterdam, The Netherlands.

Stadt Freising. 2014/15. Stadtentwicklungsplan StEP 2030. City of Freising, Freising, Germany.

Stadt München. 2001. Perspektive München. City of Munich, Munich, Germany. Note that the latest revision is from 2010

Stadt München. 2010. Klimaschutzprogramm 2010 der Landeshauptstadt München. Kurzbeschreibung des Klimaschutzprogramms. City of Munich, Munich, Germany.

Stadt München. 2012a. Leitlinie Ökologie: Teil Klimawandel und Klimaschutz. City of Munich, Munich, Germany.

Stadt München. 2012b. Integriertes Handlungsprogramm Klimaschutz in München (IHKM). Klimaschutzprogramm 2013. City of Munich, Munich, Germany.

Stadt München. 2012c. Nachhaltigkeitsaspekte in Bebauungsplänen. ee concept GmbH for the City of Munich, Munich, Germany.

Stadt Nürnberg. 2009. Nürnberg Nachhaltig. City of Nuremberg, Nuremberg, Germany.

Stadt Nürnberg. 2012a. Handbuch Klimaanpassung: Bausteine für die Nürnberger Anpassungsstrategie. City of Nuremberg, Nuremberg, Germany.

Stadt Nürnberg. 2012b. Grün- und Freiraumkonzept Weststadt. City of Nuremberg, Nuremberg, Germany.

Stadt Nürnberg. 2014. Klimafahrplan Nürnberg 2010-2050. City of Nuremberg, Nuremberg, Germany.

Stadt Nürnberg. [date unknown]. Förderprogramm Grün in der Altstadt. City of Nuremberg, Nuremberg, Germany.

Stadt Passau. 2012. Stadtentwicklungskonzept Passau. City of Passau, Passau, Germany.

Stadt Regensburg. 2012a. Managementplan UNESCO-Welterbe 'Altstadt Regensburg mit Stadtamhof'. City of Regensburg, Regensburg, Germany.

Stadt Regensburg. 2012b. Blühendes Regensburg: Sonderwettbewerb 'Begrünter Innenhof'. City of Regensburg, Regensburg, Germany.

Stadt Regensburg. 2014/15. Städtebauliches Rahmenkonzept Innenstadt (SRK). City of Regensburg, Regensburg, Germany.

Stratigaki, M. 2005. Gender mainstreaming vs positive action: an ongoing conflict in EU gender equality policy. European Journal of Women's Studies 12:165-186. http://dx.doi.org/10.1177/13505$\underline{06805051236}$

Swart, R., and F. Raes. 2007. Making integration of adaptation and mitigation work: mainstreaming into sustainable development policies? Climate Policy 7:288-303. http://dx.doi. org/10.1080/14693062.2007.9685657 
The Economics of Ecosystems and Biodiversity (TEEB). 2010. Mainstreaming the economics of nature: a synthesis of the approach, conclusions and recommendations of TEEB. TEEB, Geneva, Switzerland. [online] URL: http://www.teebweb.org/ publication/mainstreaming-the-economics-of-nature-a-synthesisof-the-approach-conclusions-and-recommendations-of-teeb/

Thompson, A., P. Robbins, B. Sohngen, J. Arvai, and T. Koontz. 2006. Economy, politics and institutions: from adaptation to adaptive management in climate change. Climate Change 78:1-5. http://dx.doi.org/10.1007/s10584-006-9095-5

Tompkins, E. L., and H. Eakin. 2012. Managing private and public adaptation to climate change. Global Environmental Change 22(1):3-11. http://dx.doi.org/10.1016/j.gloenvcha.2011.09.010

Tongco, M. 2007. Purposive sampling as a tool for informant selection. Ethnobotany Research and Applications 5:147-158.

True, J. 2010. Mainstreaming gender in international institutions. Pages 189-203 in L. J. Shepherd, editor. Gender matters in global politics: a feminist introduction to international relations. Routledge, New York, New York, USA.

Turnhout, E., C. Waterton, K. Neves, and M. Buizer. 2013. Rethinking biodiversity: from goods and services to "living with". Conservation Letters 6:154-161. http://dx.doi.org/10.1111/ j.1755-263X.2012.00307.X

Turnpenny, J., D. Russel, and A. Jordan. 2014. The challenge of embedding an ecosystem services approach: patterns of knowledge utilisation in public policy appraisal. Environment and Planning C: Government and Policy 32:247-262. http://dx.doi. org/10.1068/c1317j

Uy, N., and R. Shaw. 2012a. Overview of ecosystem-based adaptation. Pages 3-17 in N. Uy and R. Shaw, editors. Ecosystembased adaptation. Community, environment and disaster risk management, Volume 12. Emerald Group, Bingley, UK.

Uy, N., and R. Shaw. 2012b. The role of ecosystems in climate change adaptation and disaster risk reduction. Pages 41-59 in N. Uy and R. Shaw, editors. Ecosystem-based adaptation. Community, environment and disaster risk management, Volume 12. Emerald Group, Bingley, UK.

van den Bergh, J. C. J. M., B. Truffer, and G. Kallis. 2011. Environmental innovation and societal transitions: introduction and overview. Environmental Innovations and Societal Transitions 1:1-23. http://dx.doi.org/10.1016/i.eist.2011.04.010

Vignola, R., B. Locatelli, C. Martinez, and P. Imbach. 2009. Ecosystem-based adaptation to climate change: what role for policy-makers, society and scientists? Mitigation and Adaptation Strategies for Global Change 14:691-696. http://dx.doi. org/10.1007/s11027-009-9193-6

Wamsler, C. 2014a. Cities, disaster risk and adaptation. Routledge series on critical introduction to urbanism and the city. Routledge, London, UK.
Wamsler, C. 2014b. Integrating climate change adaptation into municipal planning and governance. (Swedish version: Integration av klimatanpassning i kommunal verksamhet och planering; German version: Integration des Themenfeldes Klimaanpassung in Stadtverwaltung und -planung). LUCSUS and ZSK/TUM, Lund, Sweden.

Wamsler, C., E. Brink, and C. Rivera. 2013. Planning for climate change in urban areas: from theory to practice. Journal of Cleaner Production 50:68-81. http://dx.doi.org/10.1016/j.jclepro.2012.12.008

Wamsler, C., C. Luederitz, and E. Brink. 2014. Local levers for change: mainstreaming ecosystem-based adaptation into municipal planning to foster sustainability transitions. Global Environmental Change 29:189-201. http://dx.doi.org/10.1016/j. gloenvcha.2014.09.008

Weber, M., and P. P. J. Driessen. 2010. Environmental policy integration: the role of policy windows in the integration of noise and spatial planning. Environment and Planning C: Government and Policy 28:1120-1134. http://dx.doi.org/10.1068/c0997

Westley, F., P. Olsson, C. Folke, T. Homer-Dixon, H. Vredenburg, D. Loorbach, J. Thompson, M. Nilsson, E. Lambin, J. Sendzimir, B. Banerjee, V. Galaz, and S. van der Leeuw. 2011. Tipping toward sustainability: emerging pathways of transformation. Ambio 40:762-780. http://dx.doi.org/10.1007/s13280-011-0186-9

Wasserhaushaltsgesetz (WHG). 2010. Wasserhaushaltsgesetz. Inkrafttreten der letzten Neufassung von 2009 (BGB1. I S. 2585; $\S 74(6)$ and 75(6).

Wasserhaushaltsgesetz (WHG). 2013. Wasserhaushaltsgesetz. Novellierung, August, 7, 2013 (BGB1. I S. 3154; § 78(3).

Wilkinson, C., T. Saarne, G. D. Peterson, and J. Colding. 2013. Strategic spatial planning and the ecosystem services concept - an historical exploration. Ecology and Society. 18(1):37. http://dx. doi.org/10.5751/ES-05368-180137

Wu, J. 2014. Urban ecology and sustainability: the state-of-thescience and future directions. Landscape and Urban Planning 125:209-221. http://dx.doi.org/10.1016/j.landurbplan.2014.01.018

Wasserwirtschaftsamt (WWA). 2011. A new lease of life for the Isar River! Wasserwirtschaftsamt, München, Germany.

Yin, R. K. 2009. Case study research: design and methods. Fourth edition. Sage, Thousand Oaks, California, USA. 